Meanwhile, two substantial issues remain to trouble Western Europe, the first of which is the reputation for being green that it appears by accident to be winning. There is nothing wrong, of course, with an ambition to be free from knowable environmental hazards, infectious diseases for example. Not is it reprehensible that people should wish that their lifespans should not be put at risk by novel sources of contamination. But there is a danger that the structure of the European Community, by giving extra brownie points to those who push for self-restraint, without consideration of the cost, will undermine the agreed and serious part of its ambition, achieving the benefits of a genuinely common market. Those elected last week to Strasbourg will be even more inclined than their predecessors to vote against the use of anabolic steroids in commercial animal husbandry, believing that to be the green course. Who will be there to count the cost?

The second issue is political or, rather, constitutional. What this Euro-election has shown is that European voters are still hopelessly divided on their long-term objectives. Neither the British Labour party (which did well) nor the right-wing parties in West Germany (similarly) are federalists. They will turn up in Strasbourg with very different kinds of fish to fry. The chances are that the next European election will be a little more meaningful, but not much. Yet there are substantial European issues to discuss, from short-range missiles to the organization of higher education. Where and to whom Europeans will in future pay taxes should provide grist enough for any politician's mill. Those last week elected (or dis-elected) to Strasbourg might spend some time in the years ahead turning questions like those into the agenda items for a genuinely European election.

\section{A brave venture}

Readers should not fail to remark the importance of the first of the letters in this week's correspondence section.

ONLY occasionally does it happen that ambitious projects for international collaboration make good sense practically as well as in the head, but there can be few who will not grasp the importance of the project described by Professor John Bahcall and his associates on page 574 of this issue. Their plan is quite simple; to found with public funds an international institute of astrophysics that will assume responsibility for future capital-intensive exploration of the Universe beyond the Earth. All of those concerned are experienced, often painfully so, at the complicated art of successful international collaboration in fields cognate with that to which their present hopes aspire. What they are saying to their colleagues and their governments is that there are simpler and more effective ways of helping astrophysicists work together than the complicated bilateral and even multilateral arrangements which are now in fashion. Why should there be a treaty, or 566 diplomatic negotiations, when practitioners know immediately what can and should be done, but need only the funds with which to do it and the freedom go to ahead?

The opportunities are immense. Why not, after Hubble, put a 10-metre telescope in geosynchronous orbit? Why not build a radio interferometer with a baseline so great that it is for practical purposes infinite? Why not make a catalogue of what remains a largely uncharted Universe that will, by approaching completeness, allow the substrates of common observations to assume their proper significance? Why not set out, in a common enterprise, to discover the machinery that keeps our larger environment in being? There is no counter-call. Indeed, this is not a field overburdened with people - compared with condensed-matter physics, for example, there are only handful of them. But there is no other field in which a few scraps of discovery can capture the general imagination as vividly. Plainly, the only reason that we do not already have an international institute of astrophysics is that nobody has thought of it before.

Naturally, there are difficulties. Why not, some will say, high-energy physics instead? There is a good case for that as well. But sadly, the major players in this field seem to have committed themselves to the next generation or half-generation - of particle accelerators. Who, at this late stage, would interview the governor of Texas to tell him that the Superconducting Super-Collidor is to be subsumed in an international enterprise? It would of course make sense that the participants in high-energy physics - Europe, Japan, the Soviet Union and the United States - should promptly sign an agreement with each other that they will not build another super-accelerator without consulting their co-signatories about the prospects of collaboration. But that agreement would bring fruit only a decade from now. Astrophysics could be a going concern by then, and could have shown how to make collaboration on the grand scale function.

There will also be smaller worries. There will be governments who fear that their brightest and best will be seduccd away by the attractions of an institute such as that proposed. Really, and if so, so what? There is hardly a field of science in which people are so mobile. There will be complaints about the cost which could be turned in 10 minutes by an accountant skilled enough to add up present costs and spell out the economics - or, better extra opportunities that would flow from collaboration. But if governments prefer to cogitate and rehearse their doubts, they should reflect on the character of the signatories of the letter on page 574 . Each of them is not only a practitioner of distinction in the field, but is or has been a public servant of an important kind - one of those in whom independence is valued above mere administration. Giacconi has been one of the most telling critics of his ultimate employer's manned space station, Sagdeev is (or should be) cherished by his employers for having donc more than most of his compatriots to make Soviet science modern, both by example and exhortation. Who will dare say such people nay? 